\title{
Assessing Knowledge, Attitude, and Practice towards COVID-19 among Sub Assistant Agriculture Officers: An Empirical Study in Bangladesh
}

\author{
Debashis Roy ${ }^{1 *}$ (D), Tilak Kumar Ghosh ${ }^{2}$ (D), Munmun Saha ${ }^{2}$ (D), Susmita Sarker ${ }^{3}$ ()
}

${ }^{1}$ Department of Agricultural Extension Education, Bangladesh Agricultural University, BANGLADESH

${ }^{2}$ Department of Agricultural Extension, Government of the People's Republic of Bangladesh, BANGLADESH

${ }^{3}$ Department of Agricultural Chemistry, Bangladesh Agricultural University, BANGLADESH

*Corresponding Author: droyagext@bau.edu.bd

Citation: Roy D, Ghosh TK, Saha M, Sarker S. Assessing Knowledge, Attitude, and Practice towards COVID-19 among Sub Assistant Agriculture Officers: An Empirical Study in Bangladesh. Journal of Contemporary Studies in Epidemiology and Public Health. 2020;1(2):ep20009. https://doi.org/10.30935/jconseph/9364

\begin{abstract}
The government of Bangladesh pays special attention to the agriculture sector to limit the current and after-effects of COVID-19 regarding food insecurity. Sub assistant agriculture officers - the frontline extension workers are working to maintain the normal trend of production and marketing amid COVID-19 pandemic, which, in turn, possess severe health threat of virus infection. Therefore, we investigated the knowledge, attitude, and practice towards COVID-19 among the sub assistant agriculture officers. The study was conducted in Gopalganj and Narail districts of Bangladesh with a total of 110 respondents. Data were collected through group interviews using a structured questionnaire in June 2020. The collected data were analyzed using descriptive statistics, chi square tests and binary logistic regressions. We found that about 66.36 percent of the respondents had good knowledge; 65.45 percent had positive attitude towards successful control and prevention; and 62.73 percent were taking good preventive practices towards COVID-19. However, still good number of the respondents had poor knowledge (33.64 percent), less positive attitude (34.55 percent) and poor practice (37.27 percent). Age, gender and service experience were significantly associated with good knowledge, and age and service experience were significantly associated with good practice. We recommend for the continuous flow of COVID-19 information from the health department as well as awareness campaigns and official circular about symptoms and preventive measures from the controlling authority, i.e. Department of Agricultural Extension. Finally, the limited sample size of the study advises to be more careful about generalizing the findings in other parts of the country.
\end{abstract}

Keywords: COVID-19, knowledge, attitude, practice, SAAOs, Bangladesh

Received: 5 Aug. $2020 \bullet$ Accepted: 15 Nov. 2020

\section{INTRODUCTION}

The world is now passing through a crucial health problem due to coronavirus disease (COVID-19) which was first detected in 2019 in Wuhan, China [1-2]. Since then, it has spread to 216 countries affecting $16,523,815$ people with $6,55,112$ deaths as of $31^{\text {st }}$ July, 2020 [3]. And it is yet to discover effective drugs or vaccine and make them available for the people [4]). Researchers characterize the disease by high morbidity and mortality rates [5-6]. Due to being a highly infectious disease, social distancing is one of the primary precautionary measures to reduce its transmission. Therefore, many governments have declared general holidays or lockdowns to stop its mass transmission and to safeguard their people.

The first COVID-19 case was detected on 08 March 2020 in Bangladesh [7], and at the time of writing this manuscript, the confirmed cases were over 2,34,889 with 3,083 deaths [8]. Still the situation is getting worsen day by day posing enormous threats to the country's overall economy, health, agriculture and other sectors. Like many other countries, Bangladesh government has executed general holidays, and to some extent strict lockdowns to stop spreading this infectious disease [4]. As a result, there has been prevailing uncertainties whether the country will be capable enough to manage after-effects of the COVID-19 pandemic.

Being a developing country, agriculture sector is to play an important role to maintain regular trend of food production and marketing for the present and future crises [9-10]. The coronavirusinduced shutdowns in Bangladesh have caused an estimated loss of 6.66 billion USD between March and May 2020 [11]. Realizing the long term impacts of COVID-19, the agriculture sector gets special attention of the government of Bangladesh [10,12] so that the country could cope with the effects. The Prime Minister of Bangladesh has been motivating the farmers to leave not even an inch of land fallow [12]. The Department of Agricultural Extension (DAE) is the government and 
core entity responsible for the advisory services regarding crop agriculture in Bangladesh [13]. With a well developed organogram, DAE provides advisory services to the farmers regarding crop production, protection and marketing. And during the current pandemic situation, DAE is still providing services to maintain food production [14].

Sub Assistant Agriculture Officers (SAAOs) are the frontline staffs of DAE who deliver extension services at the door of the farmers [15]. They usually work at the block level (each block consists of 900-1000 farm households), and are responsible to implement any agricultural programme with proper supervision of Sub-district Agriculture Officers (UAO) and Agriculture Extension Officers (AEO) in the field level. Apart from agriculture, they also play role in building awareness of the rural community regarding any urgent situation. However, in view of accelerating the food security for the current and future crises, and due to the pick crop growing session, SAAOs are working hard to deliver their services during this COVID-19 pandemic. This in turn possesses serious health threats to SAAOs of being infected by COVID19 , if proper precautionary measures are not taken. Literature suggests that the lack of knowledge or misconception can lead to the virus infection, spread of disease and poor preventive practices [16-17]. The successful control of the COVID-19 crisis is highly associated with people's adherence to the preventive measures which is affected by their knowledge, attitude and practice (KAP) [18-19]. The KAP studies provide baseline information about the types of intervention required, and help determine people's readiness to accept behavioural change measures to cope with COVID-19 [1]. From this background, the present study was designed to assess the KAP of the SAAOs regarding COVID-19. A good volume of studies were found assessing KAP regarding COVID-19 among general public in Bangladesh [20-25]. To the best of our knowledge, no such study was conducted yet to address SAAO's KAP towards COVID-19. Therefore, the present study was conducted to assess knowledge, attitude and practice towards COVID19 among SAAOs, and to determine the factors associated with KAP among SAAOs.

\section{MATERIALS AND METHODS}

\section{Study Location and Participants}

A cross-sectional survey was conducted to attain the objectives of the study. The study was conducted in five sub-districts (upazila) of Narail and Gopalganj districts, Bangladesh (Figure 1). The location was
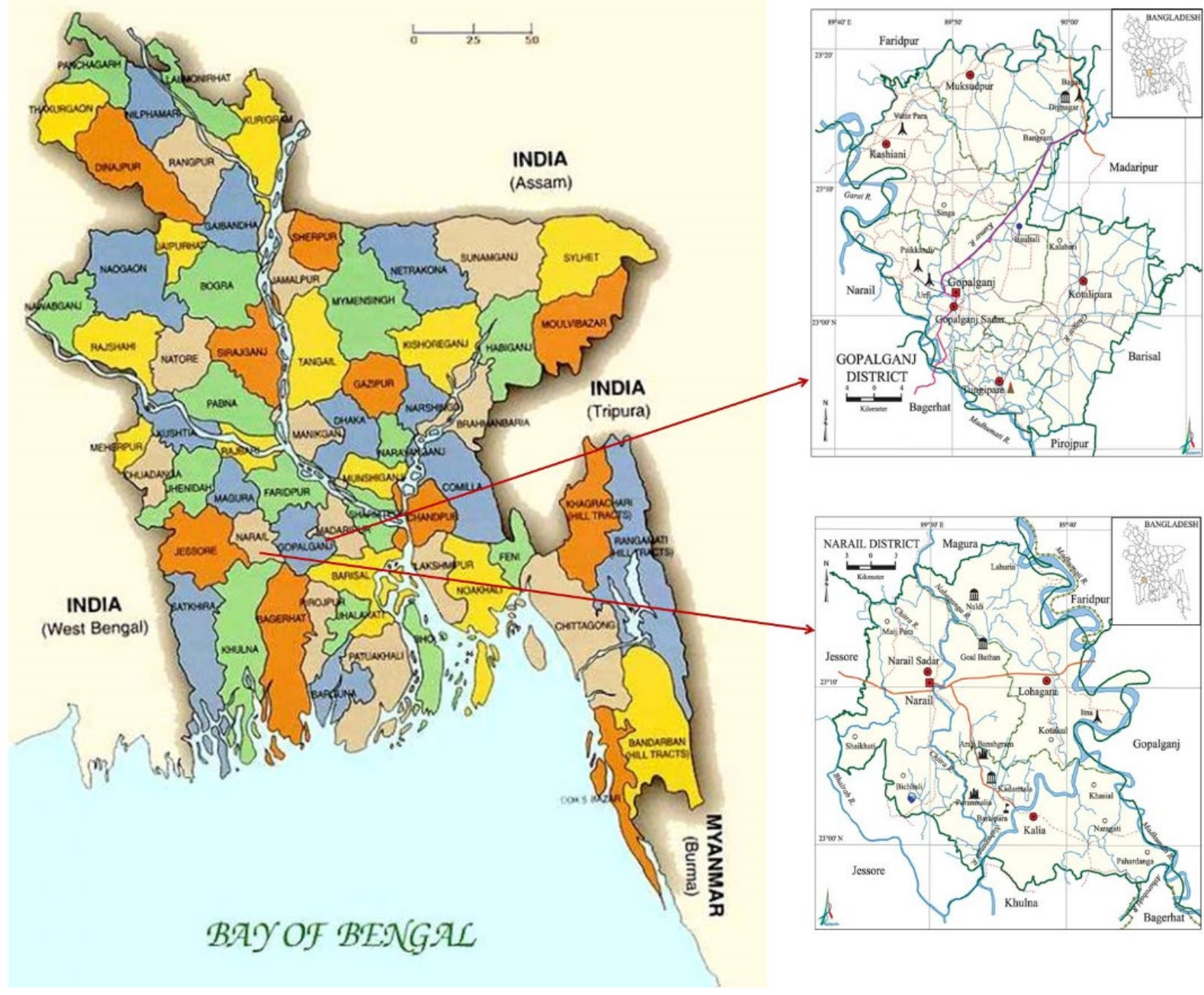

Figure 1. Map showing study areas

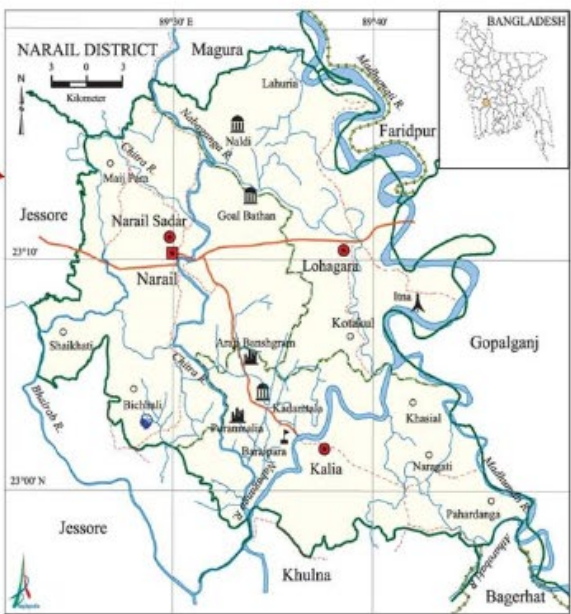


selected purposively for easy accessibility and availability and willingness of the respondents to participate in the survey. A census method was used to select all the SAAOs for data collection. There were a total of 122 SAAOs working for agriculture office in the five studied sub-districts; however, 110 SAAOs were participated in the final survey. Group interviews were conducted with a structured questionnaire for data collection. Preventive practices such as wearing mask, maintaining social distance ( 3 feet) and hand hygiene were carefully maintained during the interviews.

\section{Survey Instrument and Data Collection}

A structured questionnaire was used to collect data from the respondents during the month of June 2020. The group interviews were conducted on the weekly meeting days of the respective subdistrict's agriculture office. The survey questionnaire is an adaptation of measures with some modifications of previously conducted studies [1$2,26]$. The survey questionnaire was further validated through expert's (i.e. two researchers of pharmacy and medical background) judge rating. The questionnaire was consisted of three parts, i) the first part sought for the socio-economic profile of the respondents, ii) the second part assessed the information sources from where the respondents collect COVID-19 information, and iii) the last part examined the KAP regarding COVID-19 among SAAOs. The questionnaire was first developed in English and then translated into Bengali language for easy understanding of the respondents.

A total of 12 measures were adapted from [1-2] to assess knowledge of the SAAOs regarding COVID-19 diseases. The items cover clinical presentations (items 1-4), transmission routes (items 5-7), and prevention and control (items 8-12) of COVID-19. The items were asked to the respondents against three possible responses of true, false and do not know. A correct answer was assigned 1, whereas 0 was assigned for an incorrect or do not know answer. Hence, the knowledge score regarding COVID-19 ranged from 0-12, where 0 indicates no knowledge and 12 indicates better knowledge.

Regarding attitude of the respondents towards COVID-19, a five point rating scale was used. Five statements on control of COVID-19, confidence on government's role, follow standard precautions, taking action when symptom is shown and impact on agriculture. The first two statements were adapted from [1-2], the rest three statements were created by the authors in consultation with experts and reviewed literature. Each statement was asked to the respondent against five possible responses, i.e. strongly agree, agree, neutral, disagree and strongly disagree with corresponding scores of 5, 4, 3, 2 and 1, respectively. The attitude score ranged from $5-25$, where 5 indicates low attitude and 25 indicates high attitude.

To assess practice to prevent COVID-29 infection, ten (10) items were adapted and asked to the respondents against yes, no and sometimes. A score 1 was assigned for yes, and 0 was assigned for no/sometimes. Thus, the practice score ranged from $0-10$, where 0 indicates no practice and 10 indicates sufficient practice. The items were adapted from the guidelines of WHO and other literature [26].

\section{Ethical Considerations}

The study was conducted in accordance with the ethical standards of 2013 Declaration of Helsinki. Before interviewing the respondents, the purpose and nature of the study, voluntary participation, confidentiality and anonymity was informed to the respondents. The respondents were free to decline at any stage of the interview process.
Table 1. Demographic characteristics of the respondents $(\mathrm{N}=110)$

\begin{tabular}{|c|c|c|c|}
\hline \multicolumn{2}{|c|}{ Demographic characters } & Number & Percentage \\
\hline \multirow{4}{*}{ Age (years) } & Up to 30 & 25 & 22.7 \\
\hline & $31-40$ & 52 & 47.3 \\
\hline & $41-50$ & 18 & 16.4 \\
\hline & Above 50 & 15 & 13.6 \\
\hline Education & Diploma in agriculture & 110 & 100.0 \\
\hline \multirow{2}{*}{ Gender } & Male & 85 & 77.3 \\
\hline & Female & 25 & 22.7 \\
\hline \multirow{2}{*}{ Marital status } & Married & 95 & 86.4 \\
\hline & Unmarried & 15 & 13.6 \\
\hline \multirow{4}{*}{$\begin{array}{c}\text { Service } \\
\text { experience } \\
\text { (years) }\end{array}$} & Up to 10 & 38 & 34.5 \\
\hline & $11-20$ & 31 & 28.2 \\
\hline & $21-30$ & 20 & 18.2 \\
\hline & Above 30 & 21 & 19.1 \\
\hline
\end{tabular}

\section{Statistical Analysis}

The data were analysed using Statistical Package for Social Science (SPSS) ver. 22 and Microsoft Excel ver. 13. Descriptive statistics such as frequencies, percentage, mean and inferential statistics such as Chi $(\chi 2)$ square test were used to report the findings. A binary logistic regression analysis was applied to identify the factors associated with good knowledge, more positive attitude and good practice. The results of the binary logistic regression were expressed as odds ratio (OR) and 95\% confidence of interval $(\mathrm{CI})$ and $\mathrm{P}<0.05$ was considered to indicate significance. Cronbach's alpha coefficient was used determine the internal consistency of knowledge, attitude and practice items. The results showed that the Cronbach's alpha coefficient for knowledge questionnaire was 0.713 , for attitude questionnaire was 0.754 , and for practice questionnaire was 0.708 , indicating acceptable internal consistency [27].

\section{RESULTS}

\section{Demographic Characteristics}

Demographic characteristics of the respondents are presented in Table 1. A total of 110 respondents willingly participated in the study. The education qualification of the SAAOs is Diploma in agriculture (100.0 percent). Out of the total, nearly half of the respondents (47.3 percent) were $31-40$ years of age. The majority of the respondents were male (77.3 percent) and married (86.4 percent). Table 1 further show that the majority of the respondents (34.5 percent) had service experience of up to 10 years followed by 28.2 percent having service experience of 10-20 years.

\section{Collection of Information about COVID-19}

The respondents were asked to indicate different information sources through which they collect information about COVID-19. The respondents would collect information through using different information sources (see Figure 2). Social media was widely used by the respondents (89.1 percent) to collect information about COVID-19. Just immediately after social media, the respondents were used to collect information through television (81.8 percent) and friends and family (79.1 percent). However, some 29.1 percent SAAOs collected information from other sources, for example, healthcare workers and colleagues. 


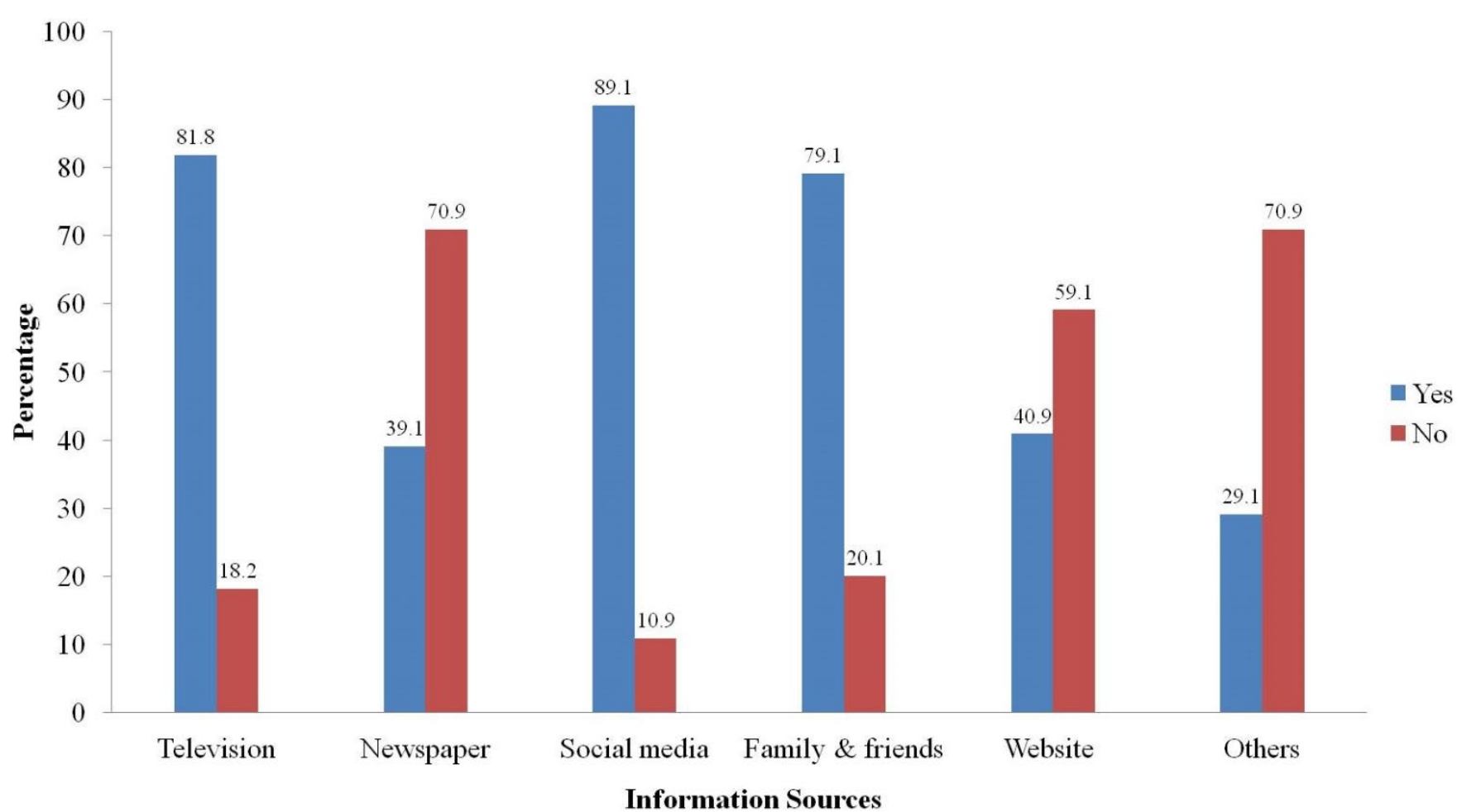

Figure 2. Sources of information about COVID-19 $(\mathrm{N}=110)$

Table 2. Knowledge of SAAOs about COVID-19 ( $\mathrm{N}=110)$

\begin{tabular}{|c|c|c|c|}
\hline \multirow{2}{*}{ Questions } & True & False & Not sure \\
\hline & $\mathrm{N}(\%)$ & $\mathrm{N}(\%)$ & $\mathrm{N}(\%)$ \\
\hline \multicolumn{4}{|l|}{ Clinical presentations (correct answer $=84.33 \%$ ) } \\
\hline 1. The main clinical symptoms of COVID-19 are fever, fatigue, dry cough, and myalgia. & $104(\mathbf{9 4 . 5 5 )}$ & $6(5.45)$ & $0(0.0)$ \\
\hline $\begin{array}{l}\text { 2. Unlike the common cold, stuffy nose, runny nose, and sneezing are less common in persons infected with the COVID-19 } \\
\text { virus. }\end{array}$ & $84(76.36)$ & $8(7.27)$ & $18(16.36)$ \\
\hline $\begin{array}{l}\text { 3. There currently is no effective cure for COVID-2019, but early symptomatic and supportive treatment can help most } \\
\text { patients recover from the infection. }\end{array}$ & $96(87.27)$ & $4(3.64)$ & $10(9.09)$ \\
\hline $\begin{array}{l}\text { 4. Not all persons with COVID-2019 will develop to severe cases. Only those who are elderly, have chronic illnesses, and are } \\
\text { obese are more likely to be severe cases. }\end{array}$ & $87(79.09)$ & $8(7.27)$ & $15(13.64)$ \\
\hline \multicolumn{4}{|l|}{ Transmission routes (correct answer $=61.52 \%$ ) } \\
\hline 5. Eating or contacting wild animals would result in the infection by the COVID-19 virus. & $73(66.4)$ & $37(33.6)$ & $0(0.0)$ \\
\hline 6. Persons with COVID-2019 cannot infect the virus to others when a fever is not present. & $23(20.91)$ & $70(63.64)$ & $17(15.45)$ \\
\hline 7. The COVID-19 virus spreads via respiratory droplets of infected individuals. & $96(\mathbf{8 7 . 2 7})$ & $5(4.55)$ & $9(8.18)$ \\
\hline \multicolumn{4}{|l|}{ Prevention and control (correct answer $=88.91 \%$ ) } \\
\hline 9. It is not necessary for children and young adults to take measures to prevent the infection by the COVID-19 virus. & $6(5.5)$ & $94(\mathbf{8 5 . 4 5 )}$ & $10(9.05)$ \\
\hline $\begin{array}{l}\text { 10. To prevent the infection by COVID-19, individuals should avoid going to crowded places such as train stations and avoid } \\
\text { taking public transportations }\end{array}$ & $104(\mathbf{9 4 . 5 5 )}$ & $6(5.45)$ & $0(0.0)$ \\
\hline $\begin{array}{l}\text { 11. Isolation and treatment of people who are infected with the COVID-19 virus are effective ways to reduce the spread of the } \\
\text { virus }\end{array}$ & $96(87.27)$ & $9(8.18)$ & $5(4.55)$ \\
\hline $\begin{array}{l}\text { 12. People who have contact with someone infected with the COVID-19 virus should be immediately isolated in a proper } \\
\text { place. In general, the observation period is } 14 \text { days. }\end{array}$ & $100(\mathbf{9 0 . 9 1 )}$ & $10(9.09)$ & $0(0.0)$ \\
\hline
\end{tabular}

Correct answers are indicated in bold

\section{Knowledge about COVID-19}

A total of twelve questions were asked to the respondents regarding COVID-19 knowledge (Table 2). The correct answer rates for all the respondents ranged from 33.6 to 94.5 percent. The average knowledge score was 8.74 with standard deviation of 2.053 . The correct answer on knowledge of clinical presentations was 84.33 percent representing an acceptable level of knowledge. Most of the respondents knew that the main clinical symptoms of COVID-19 are fever, fatigue, dry cough and myalgia (94.5 percent). However, still approximately 23.63 percent of the SAAOs either did not know or wrongly perceived the common cold symptoms as COVID-19 symptoms, and around 36.36 percent of the SAAOs were unaware that a COVID-19 infected person without fever can also spread the virus. The correct answer regarding knowledge on transmission routes of the virus was 61.52 percent. There is still confusion about transmission route, and only 33.6 percent of the respondent answered correctly when we asked them whether eating or touching wild animals would transmit the virus. Table 2 further shows that the correct knowledge score about prevention and control was 
Table 3. Differences in knowledge of the SAAOs by demographics $(\mathrm{N}=110)$

\begin{tabular}{|c|c|c|c|c|c|}
\hline \multirow{2}{*}{\multicolumn{2}{|c|}{ Demographic characters }} & \multicolumn{2}{|c|}{ Knowledge } & \multirow{4}{*}{$\chi^{2}$} & \multirow{3}{*}{ p value } \\
\hline & & $\begin{array}{c}\text { Poor } \\
\mathrm{N}(\%)\end{array}$ & \multirow{2}{*}{$\begin{array}{c}\text { Good } \\
\mathrm{N}(\%) \\
\end{array}$} & & \\
\hline & & & & & \\
\hline Overall & & $37(33.64)$ & $73(66.36)$ & & \\
\hline \multirow{4}{*}{ Age (years) } & Up to 30 & $12(48.0)$ & $13(52.0)$ & \multirow{4}{*}{10.581} & \multirow{4}{*}{.014} \\
\hline & $31-40$ & $21(40.38)$ & $31(59.62)$ & & \\
\hline & $41-50$ & $3(16.67)$ & $15(83.33)$ & & \\
\hline & Above 50 & $1(6.67)$ & $14(93.33)$ & & \\
\hline \multirow{2}{*}{ Gender } & Male & $24(28.24)$ & $61(71.76)$ & \multirow{2}{*}{.027} & \multirow{2}{*}{.033} \\
\hline & Female & $13(52.0)$ & $12(48.0)$ & & \\
\hline \multirow{2}{*}{ Marital status } & Married & $33(34.74)$ & $62(65.26)$ & \multirow{2}{*}{.539} & \multirow{2}{*}{.770} \\
\hline & Unmarried & $4(26.67)$ & $11(73.33)$ & & \\
\hline \multirow{4}{*}{ Service experience (years) } & Up to 10 & $12(31.58)$ & $26(68.42)$ & \multirow{4}{*}{9.218} & \multirow{4}{*}{.027} \\
\hline & $11-20$ & $5(16.13)$ & $26(83.87)$ & & \\
\hline & $21-30$ & $11(55.0)$ & $9(45.0)$ & & \\
\hline & Above 30 & $9(42.86)$ & $12(57.14)$ & & \\
\hline
\end{tabular}

$\mathrm{P}<0.05$ was considered to indicate significance.

Overall knowledge scores ranged from $0-12$.

A score of $\leq 8$ was set for poor knowledge and $>8$ was set for good knowledge.

Table 4. Factors associated with good knowledge about COVID-19 ( $\mathrm{N}=110)$

\begin{tabular}{|c|c|c|c|c|c|}
\hline \multirow{2}{*}{\multicolumn{2}{|c|}{ Demographic characters }} & \multirow{2}{*}{ OR } & \multirow{2}{*}{ P value } & \multicolumn{2}{|c|}{ 95\% CI } \\
\hline & & & & Lower & Upper \\
\hline \multirow{4}{*}{ Age (years) } & Up to 30 & .012 & .001 & .001 & .163 \\
\hline & $31-40$ & .017 & .001 & .002 & .183 \\
\hline & $41-50$ & .050 & .028 & .003 & .718 \\
\hline & Above 50 & 1.00 & & & \\
\hline Gender & Male & 4.042 & .020 & 1.249 & 13.082 \\
\hline \multirow{2}{*}{ Marital status } & Married & .510 & .365 & .119 & 2.191 \\
\hline & Unmarried & 1.00 & & & \\
\hline \multirow{4}{*}{ Service experience (years) } & Up to 10 & 4.608 & .040 & 1.075 & 19.742 \\
\hline & $11-20$ & 9.302 & .006 & 1.913 & 45.224 \\
\hline & $21-30$ & .581 & .513 & .114 & 2.962 \\
\hline & Above 30 & 1.00 & & & \\
\hline
\end{tabular}

CI: confidence of interval, OR: odds ratio

88.91 percent representing an acceptable level of knowledge. The majority of the respondents knew that they should avoid going crowed places (94.5 percent) to prevent COVID-19 transmission.

Difference in knowledge scores about COVID-19 by different demographic characteristics of the respondents was assessed using chi $(\chi 2)$ square test. The study found that the majority of the respondents (66.36 percent), i.e. around six in every ten SAAOs, had good knowledge about COVID-19. The findings in Table 3 show that the knowledge scores were significantly different across age, gender and service experience. The respondents of above 50 years of age had significantly greater knowledge ( 93.33 percent, $p$-value $=.014$ ) than the other age groups which is significant. Male respondents had significantly higher knowledge about COVID-19 (71.76 percent, pvalue $=.033$ ) than female respondents. The results also show a significant difference in knowledge scores among service experience groups ( $p$-value $=.027$ ) implying that the respondents who had service experience of $10-20$ years had greater knowledge ( 83.87 percent) over the other service experience groups.

The outputs of the binary logistic regression as presented in Table 4 reveal that the age-groups of up to 30 years of age (OR:.012, P = 0.001), 31-40 years (OR:.017, $\mathrm{P}=0.001$ ) and $41-50$ years (OR:.050, $\mathrm{P}$
$=.028)$; male respondents ( $\mathrm{OR}: 4.042, \mathrm{P}=0.020)$; service experience groups of up to 10 years (OR: $4.608, \mathrm{P}=.040)$ and $10-20$ years (OR: 9.302, $\mathrm{P}=.006$ ) were significantly associated with good knowledge of the SAAOs about COVID-19.

\section{Attitude of SAAOs towards COVID-19}

The respondents were asked to respond to five questions concerning their attitude towards COVID-19 (Table 5). For the first question, the majority of the respondents (74.6 percent) had confidence that Bangladesh would be able to control COVID-19. Over 66.3 percent respondents agreed that the Bangladesh government was handling the COVID-19 crisis well. Table 5 suggests that an overwhelming majority of the respondents ( 97.3 percent) agreed to follow the precautionary measures to prevent COVID-19 transmission, and an 82.7 percent of the respondents agreed to call to the hotline number if any symptom is observed. Finally, over half of the respondents (51.0 percent) agreed that COVID-19 will have long term negative impact on agriculture in Bangladesh, whereas 32.7 percent of them disagreed with the question. 
Table 5. Attitude of the SAAOs towards COVID-19 $(\mathrm{N}=110)$

\begin{tabular}{|c|c|c|c|c|c|}
\hline \multirow{3}{*}{ Statements } & \multicolumn{5}{|c|}{ Level of agreement } \\
\hline & SA & $\mathrm{A}$ & $\mathrm{N}$ & $\mathrm{D}$ & $\mathrm{SD}$ \\
\hline & $\mathrm{N}(\%)$ & $\mathrm{N}(\%)$ & $\mathrm{N}(\%)$ & $\mathrm{N}(\%)$ & $\mathrm{N}(\%)$ \\
\hline 1. Do you agree that COVID-19 will finally be successfully controlled? & $50(45.5)$ & $32(29.1)$ & $25(22.7)$ & $1(.9)$ & $2(1.8)$ \\
\hline 2. Bangladesh govt. is handling the COVID-19 health crisis very well. & $38(34.5)$ & $35(31.8)$ & $15(13.6)$ & $22(20.0)$ & $0(0.0)$ \\
\hline $\begin{array}{l}\text { 3. We should follow the precautions set by the Ministry of Health and WHO to prevent COVID-19 } \\
\text { transmission. }\end{array}$ & $66(60.0)$ & $41(37.3)$ & $3(2.7)$ & $0(0.0)$ & $0(0.0)$ \\
\hline 4. We should call to hotline number provided by the Ministry of Health if any symptom is observed. & $55(50.0)$ & $36(32.7)$ & $16(14.5)$ & $3(2.7)$ & $0(0.0)$ \\
\hline 5. COVID-19 will have long term negative impact on agriculture. & $17(15.5)$ & $39(35.5)$ & $18(16.4)$ & $34(30.9)$ & $2(1.8)$ \\
\hline
\end{tabular}

Table 6. Differences in attitude of the SAAOs by demographics $(\mathrm{N}=110)$

\begin{tabular}{|c|c|c|c|c|c|}
\hline \multirow{2}{*}{\multicolumn{2}{|c|}{ Demographic characters }} & \multicolumn{2}{|c|}{$\begin{array}{l}\text { Attitude } \\
\end{array}$} & \multirow{3}{*}{$x^{2}$} & \multirow{3}{*}{ p value } \\
\hline & & \multirow{2}{*}{$\begin{array}{c}\text { Less positive } \\
\mathrm{N}(\%) \\
\end{array}$} & \multirow{2}{*}{$\begin{array}{c}\text { More positive } \\
\mathrm{N}(\%) \\
\end{array}$} & & \\
\hline & & & & & \\
\hline Overall & & $38(34.55)$ & $72(65.45)$ & & \\
\hline \multirow{4}{*}{ Age (years) } & Up to 30 & $15(60.0)$ & $10(40.0)$ & \multirow{4}{*}{10.104} & \multirow{4}{*}{.018} \\
\hline & $31-40$ & $16(30.77)$ & $36(69.23)$ & & \\
\hline & $41-50$ & $4(22.22)$ & $14(77.78)$ & & \\
\hline & Above 50 & $3(20.0)$ & $12(80.0)$ & & \\
\hline \multirow{2}{*}{ Gender } & Male & $26(30.59)$ & $59(69.41)$ & \multirow{2}{*}{.108} & \multirow{2}{*}{.150} \\
\hline & Female & $12(48.0)$ & $13(52.0)$ & & \\
\hline \multirow{2}{*}{ Marital status } & Married & $32(33.68)$ & $63(66.32)$ & \multirow{2}{*}{.633} & \multirow{2}{*}{.771} \\
\hline & Unmarried & $6(40.0)$ & $9(60.0)$ & & \\
\hline \multirow{4}{*}{ Service experience (years) } & Up to 10 & $11(28.95)$ & $27(71.05)$ & \multirow{4}{*}{6.189} & \multirow{4}{*}{.103} \\
\hline & $11-20$ & $7(22.58)$ & $24(77.42)$ & & \\
\hline & $21-30$ & $10(50.0)$ & $10(50.0)$ & & \\
\hline & Above 30 & $10(47.62)$ & $11(52.38)$ & & \\
\hline
\end{tabular}

$\mathrm{P}<0.05$ was considered to indicate significance.

Overall attitude scores ranged from $0-25$.

A score of $\leq 18$ was set for less positive and $>18$ was set for more positive attitude.

Table 7. Factors associated with positive attitude towards COVID-19 $(\mathrm{N}=110)$

\begin{tabular}{|c|c|c|c|c|c|}
\hline \multirow{2}{*}{\multicolumn{2}{|c|}{ Demographic characters }} & \multirow{2}{*}{ OR } & \multirow{2}{*}{ P value } & \multicolumn{2}{|c|}{ 95\% CI } \\
\hline & & & & Lower & Upper \\
\hline \multirow{4}{*}{ Age (years) } & Up to 30 & .195 & .211 & .015 & 2.521 \\
\hline & $31-40$ & 2.117 & .527 & .207 & 21.640 \\
\hline & $41-50$ & .978 & .986 & .080 & 11.907 \\
\hline & Above 50 & 1.00 & & & \\
\hline \multirow{2}{*}{ Gender } & Male & 1.421 & .632 & .338 & 5.981 \\
\hline & Female & 1.00 & & & \\
\hline \multirow{2}{*}{ Marital status } & Married & 2.422 & .285 & .479 & 12.244 \\
\hline & Unmarried & 1.00 & & & \\
\hline \multirow{4}{*}{ Service experience (years) } & Up to 10 & 5.176 & .102 & .723 & 37.047 \\
\hline & $11-20$ & 1.638 & .630 & .220 & 12.208 \\
\hline & $21-30$ & 2.213 & .433 & .304 & 16.104 \\
\hline & Above 30 & 1.00 & & & \\
\hline
\end{tabular}

CI: confidence of interval, OR: odds ratio

The overall attitude score $($ Mean $=20.1818, \mathrm{SD}=3.307)$ shows that the respondents had highly positive attitude towards control of COVID-19 (Table 6). The chi $(\chi 2)$ square results show that there was significant difference in the attitude scores among age groups ( $p$-value $=.018$ ). The respondents of above 50 years of age had significant and positive attitude towards COVID-19 control compared with other age groups (80.0 percent). Although our findings found an overall more positive attitude towards COVID-19 control (Table 6), prevention and impacts, interestingly, the binary logistic regression outputs suggest that the positive attitude of the SAAOs towards COVID-19 was significantly associated with demographic characteristics (Table 7).

\section{Preventive Practice towards COVID-19}

A total of ten questions concerning prevention and control of COVID were used to measure the practice of the respondents (Table 8). The average practice score was 7.696 with standard deviation of 2.018. The results show that 93.6 percent of the respondents were wearing mask when leaving home. The results further show that a significant number of the respondents were maintaining hand hygiene (89.1 percent). Another 87.3 percent of the respondents were avoiding touching eyes, nose or mouth, and over 81.8 percent of them were maintaining social distance in the work or public places. Although the 
Table 8. Preventive practice towards COVID-19 $(\mathrm{N}=110)$

\begin{tabular}{|c|c|c|c|}
\hline \multirow{2}{*}{ Practices } & Yes & No & Sometimes \\
\hline & $\mathrm{N}(\%)$ & $\mathrm{N}(\%)$ & $\mathrm{N}(\%)$ \\
\hline 1. Do you avoid crowded place? & $75(68.2)$ & $33(30.0)$ & $2(1.8)$ \\
\hline 2. Do you wear a mask when leaving home? & $103(93.6)$ & $7(6.4)$ & - \\
\hline 3. Do you maintain hand hygiene? & $98(89.1)$ & $8(7.3)$ & $4(3.6)$ \\
\hline 4. Do you maintain social distance when in work/public place? & $90(81.8)$ & $12(10.9)$ & $8(7.3)$ \\
\hline 5. Do you avoid touching your eyes, nose or mouth as far as you can? & $96(87.3)$ & $9(8.2)$ & $5(4.5)$ \\
\hline 6. Do you eat nutritious foods to improve immunity? & $84(76.4)$ & $24(21.8)$ & $2(1.8)$ \\
\hline 7. Do you avoid visitors to the house? & $79(71.8)$ & $24(21.8)$ & $7(6.4)$ \\
\hline 8. Do you go outside of home only for urgent need? & $74(67.3)$ & $30(27.3)$ & $6(5.5)$ \\
\hline 9. Do you cover your nose and mouth with a tissue during sneezing or coughing? & $67(60.9)$ & $38(34.5)$ & $5(4.5)$ \\
\hline 10. Do you throw the used tissue in the trash? & $60(54.5)$ & $46(41.8)$ & $4(3.6)$ \\
\hline
\end{tabular}

Table 9. Differences in practice of the SAAOs by demographics $(\mathrm{N}=110)$

\begin{tabular}{|c|c|c|c|c|c|}
\hline \multirow{2}{*}{\multicolumn{2}{|c|}{ Demographic characters }} & \multicolumn{2}{|c|}{ Practice } & \multirow{4}{*}{$x^{2}$} & \multirow{3}{*}{ p value } \\
\hline & & $\begin{array}{c}\text { Poor } \\
N(\%) \\
\end{array}$ & \multirow{2}{*}{$\begin{array}{c}\text { Good } \\
\mathrm{N}(\%) \\
\end{array}$} & & \\
\hline & & & & & \\
\hline Overall & & $41(37.27)$ & $69(62.73)$ & & \\
\hline \multirow{4}{*}{ Age (years) } & Up to 30 & $9(36.0)$ & $16(64.0)$ & \multirow{4}{*}{1.422} & \multirow{4}{*}{.700} \\
\hline & $31-40$ & $22(42.31)$ & $30(57.69)$ & & \\
\hline & $41-50$ & $6(33.33)$ & $12(66.67)$ & & \\
\hline & Above 50 & $4(26.67)$ & $11(73.33)$ & & \\
\hline \multirow{2}{*}{ Gender } & Male & $28(32.94)$ & $57(67.06)$ & \multirow{2}{*}{3.001} & \multirow{2}{*}{.083} \\
\hline & Female & $13(52.0)$ & $12(48.0)$ & & \\
\hline \multirow{2}{*}{ Marital status } & Married & $36(37.89)$ & $59(62.11)$ & \multirow{2}{*}{.115} & \multirow{2}{*}{.734} \\
\hline & Unmarried & $5(33.33)$ & $10(66.67)$ & & \\
\hline \multirow{4}{*}{ Service experience (years) } & Up to 10 & $8(21.05)$ & $30(78.95)$ & \multirow{4}{*}{9.698} & \multirow{4}{*}{.021} \\
\hline & $11-20$ & $11(35.48)$ & $20(64.52)$ & & \\
\hline & $21-30$ & $12(60.0)$ & $8(40.0)$ & & \\
\hline & Above 30 & $10(47.62)$ & $11(52.38)$ & & \\
\hline
\end{tabular}

$\mathrm{P}<0.05$ was considered to indicate significance.

Overall practice scores ranged from $0-10$.

A score of $\leq 6$ was set for poor practice and $>6$ was set for good practice.

Table 10. Factors associated with good practice towards COVID-19 $(\mathrm{N}=110)$

\begin{tabular}{|c|c|c|c|c|c|}
\hline \multirow{2}{*}{\multicolumn{2}{|c|}{ Demographic characters }} & \multirow{2}{*}{ OR } & \multirow{2}{*}{ P value } & \multicolumn{2}{|c|}{ 95\% CI } \\
\hline & & & & Lower & Upper \\
\hline \multirow{4}{*}{ Age (years) } & Up to 30 & .275 & .163 & .045 & 1.686 \\
\hline & $31-40$ & .180 & .028 & .039 & .829 \\
\hline & $41-50$ & .218 & .101 & .035 & 1.345 \\
\hline & Above 50 & 1.00 & & & \\
\hline \multirow{2}{*}{ Gender } & Male & 2.306 & .107 & .834 & 6.379 \\
\hline & Female & 1.00 & & & \\
\hline \multirow{2}{*}{ Marital status } & Married & 1.098 & .893 & .283 & 4.254 \\
\hline & Unmarried & 1.00 & & & \\
\hline \multirow{4}{*}{ Service experience (years) } & Up to 10 & 5.222 & .020 & 1.300 & 20.974 \\
\hline & $11-20$ & 2.417 & .202 & .623 & 9.373 \\
\hline & $21-30$ & .613 & .483 & .156 & 2.409 \\
\hline & Above 30 & 1.00 & & & \\
\hline
\end{tabular}

CI: confidence of interval, OR: odds ratio

majority respondents (68.2 percent) were avoiding crowded place, but still a good number of them did not avoid crowded place (30.0 percent).

The results shown in Table 9 reveal that the majority of the respondents (62.73 percent) reported good practice to prevent and control COVID-19. The chi $(\chi 2)$ square results reveal that there was significant difference in practice scores between service experience group ( $p$-value $=.021$ ) (Table 9). The respondents having service experience of up to 10 years (78.95 percent) were more likely to have good practice compared with other respondents having service experience more than 10 years. From the outputs of binary logistic regression (Table 10), we found that the respondents of 31-40 years of age (OR:.180, $\mathrm{P}=0.028)$; and service experience of up to 10 years (OR: $5.222, \mathrm{P}=0.020$ ) were significantly associated with good practice of the respondents. 


\section{DISCUSSION}

To the best of our knowledge, this is the first study investing KAP towards COVID-19 among SAAOs in Bangladesh. The purpose of this study was to explore the knowledge, attitude and practice towards COVID-19 and associated factors. The study found that the most of the SAAOs were using social media to collect information about COVID19 (Figure 2). The possible explanation could be that the respondents were relying heavily on social media during the lockdowns, and this can be justified by a study [28], reporting that the use of internet has been increased by $15-20$ percent during the lockdowns in Bangladesh. Some other studies [19-20] reported similar to our finding. Next to the social media, television and friends and family were important information sources of COVID-19 (Figure 2). These findings are consistent with a study in Pakistan [17], where reported that the healthcare workers were using social media followed by television and radio for collecting information about COVID-19. Other researchers [29-31] also reported similar findings.

Average knowledge score of the SAAOs was $8.74 \pm 2.053$, suggesting an overall 72.83 percent $\left(8.74 / 12^{*} 100\right)$ correct rate on the knowledge test. Although most of the SAAOs had good knowledge of about COVID-19, there is still need to increase knowledge of about 33.64 percent of them (Table 3). However, our good knowledge score is higher than the previously recorded good knowledge among Bangladeshi people [20, 22], but lower than the Chinese people [2]. Our findings differ with a study [24], reporting inaccurate knowledge of the people of Bangladesh about COVID-19. The findings indicate that the SAAOs were having sufficient knowledge COVID-19 symptom and preventive measures, but noticeable confusion was found in case of transmission routes of the virus (Table 2). For instance, only 33.6 percent SAAOs answered correctly regarding the question 'whether touching or eating wild animals can spread COVID-19'. Possibly the overload of information may be responsible for this confusion [1]. This implies that dissemination of concrete information regarding transmission of the virus is inevitable. The findings are consistent with some other studies in Bangladesh [20,25] and Malaysia [1].

The SAAOs above 50 years of age had significantly higher knowledge about COVID-19 (Table 3). A possible explanation may be that the elderly people are perceived as high risk of COVID-19 infection $(1,32)$. A research in Malaysia [1] found that the respondents of above 50 years of age had higher knowledge about COVID-19. The study in China [2] supports our findings, but other studies [20,24] differ that the younger people had significantly adequate knowledge about COVID-19 in Bangladesh. We also found that the male respondents had higher knowledge about COVID-19. This finding is in line with a study in China [2], but another study reported that female had adequate knowledge about COVID-19 in Bangladesh [20]. The study also suggests that SAAOs having service experience of 10-20 years had higher knowledge about COVID-19. Binary logistic regression reveals that the age of the SAAOs were significantly associated with good knowledge (Table 4), and older respondents were more likely to have good knowledge about COVID-19. This finding justifies the higher knowledge of elderly people (Table 3). Similarly, male respondents were likely to have good knowledge, possibly due to their exposure to internet facilities and information collection behavior. A study [2] supports this finding by reporting that the female respondents were associated with poor knowledge about COVID-19 in China. The findings also suggest that the SAAOs of early and mid level service experience were more likely to have good knowledge about COVID19.

The study indicated an overall positive attitude of the SAAOs towards COVID-19. Roughly eight out ten respondents showed positive attitude towards control of COVID-19 (Table 6). The finding is consistent with other studies in Bangladesh [20,24]. However, a study [25] differs with our finding that the majority of the respondents had negative attitude towards COVID-19 control in Bangladesh. Other researchers $[17,30]$ also reported positive attitude of the respondents towards COVID-19 in their respective studies. Similar to a study in Bangladesh [20], we also found the majority of the respondents were confident about successful control of COVID-19. However, the findings contradict with another study [25], where reported that the COVID-19 situation will not remain under control. Other studies [1,2] support our finding. The SAAOs agreed that Bangladesh was handling the COVID-19 issue very well (Table 5), which is similar to a previous study in Bangladesh [20]. The good sign is - the SAAOs were determined to follow the precautionary measures set the WHO and to call to hotline number of provided by the Department of Health, Bangladesh. Possibly the SAAOs were conscious about the risks of COVID-19 and the Department of Health of Bangladesh could disseminate the proper information to the respondents. In addition, adequate knowledge of the SAAOs might have influenced to form positive attitude to take preventing measures. Although debatable, the majority of the SAAOs suspected that COVID-19 will have long term impact on agriculture of Bangladesh. This may be due to the SAAO's perceived barriers in providing advisory services to the farmers, expected market failure and unavailability of agricultural inputs due to COVID-19.

Older respondents had comparatively more positive attitude towards COVID-19 (Table 6). This may be due to more concern of the elderly and their higher knowledge about COVID-19 (see Table 3). Some researches [20,24-25] support these findings that the elderly respondents (30 years of age and above) showed positive attitude towards COVID-19 in Bangladesh. A Pakistan based study [17] differs with our findings reporting that attitude regarding COVID-19 did not differ significantly with age. Regarding factors associated with positive attitude (Table 7), we found that positive attitude was not influenced by age, gender, experience and occupation. This is also similar to a study in Pakistan [17]. On the contrary, a previous study [24] found that people's attitude towards COVID-19 was significantly associated with age in Bangladesh.

The findings reveal that the majority of the SAAOs had good practice towards COVID-19 (Table 9). The finding may be due to that the SAAOs were having good knowledge and more positive attitude towards COVID-19 [25]. However, the finding clearly indicates that a good percentage of the SAAOs (approximately 37.27 percent) are yet to follow good practices to prevent COVID-19 infection. Some previous studies in Bangladesh $[20,24]$ also reported similar findings. Although the majority respondents were avoiding crowded place, but still a good number of them did not avoid crowded place. This finding is somewhat alarming as public gathering is one of the major routes for COVID-19 transmission [33]. Cultural norms might be influencing the decision of not avoiding public places despite the health risks [1]. The finding is consistent with another study [20], who found that around 37.9 percent Bangladeshi young adults either occasionally or never avoided crowded 
place. The practice score differed significantly among service experience groups, i.e. SAAOs of up to 10 years of service experience had more practice towards COVID-19 (Table 9). A study in China [33] reported that the respondents having service experience of 5-9 years were more likely to stay at home with family members. Concerning factors associated with good practice (Table 10), we found age and service experience had influence on good practice towards COVID-19. The good practice was significantly associated with age and service experience in Pakistan as well [17].

\section{LIMITATIONS OF THE STUDY}

Firstly, the study adapted KAP measures, some measures were self administered though, from previous surveys in a different country context. To adequately assess the KAP in our context, the measures should be revised and fine-tuned by some qualitative methods, for instance, focus group discussions, in-depth interviews and observations. Secondly, the study was confined in two districts of Bangladesh covering only 110 SAAOs; therefore, the sample representativeness may limit the generalisability of the findings on SAAOs in other parts of the country.

\section{CONCLUSIONS}

Our findings indicate that the SAAOs of the studied sub-districts had good knowledge, positive attitude and good practice towards COVID-19. At the same time, the findings suggest that an unavoidable number of the respondents need to increase their knowledge level, attitude and practices. We found that age, gender and service experience of the SAAOs were significantly associated with good knowledge and good practice towards COVID-19. Therefore, continuous COVID-19 information dissemination by the government and health authorities is the key to improve the same. On the other hand, the controlling authority of the SAAOs, i.e. Department of Agricultural Extension (DAE) should take initiatives, for example, awareness campaigns, official circular about COVID-19 symptoms and protective measures, to increase knowledge and practices of the SAAOs to combat COVID-19.

\section{ACKNOWLEDGEMENTS}

The authors extend their sincere thanks to all the Sub Assistant Agriculture Officers for their contribution towards the survey.

\section{REFERENCES}

1. Azlan AA, Hamzah MR, Sern TJ, Ayub SH, Mohamad E. Public knowledge, attitudes and practices towards COVID-19: A crosssectional study in Malaysia. PLoS ONE, 2020; 15: 1-15. (doi: 10.1371/journal.pone.0233668).
2. Zhong B, Luo W, Li H, Zhang Q, Liu X, Li W, Li Y. Knowledge, attitudes, and practices towards COVID-19 among Chinese residents during the rapid rise period of the COVID-19 outbreak: a quick online cross-sectional survey. Int J Bio Sci. 2020; 16(10): 1745-52. (doi: 10.7150/ijbs.45221).

3. World Health Organization. Coronavirus disease (COVID-19) pandemic. Geneva, Switzerland 2020. Available at: https://www. who.int/emergencies/diseases/novel-coronavirus-2019?gclid= EAIaIQobChMIwr-ApYP36gIVTw4rCh0zkwudEAAYAiAAEgI nHfD_BwE (Accessed: 31 July 2020).

4. Anwar S, Nasrullah M, Hosen MJ. COVID-19 and Bangladesh: Challenges and How to Address Them. Front. Pub Health. 2002; 8: 154. (doi: 10.3389/fpubh.2020.00154).

5. Reuben RC, Danladi MMA, Saleh DA, Ejembi PE. Knowledge, Attitudes and Practices Towards COVID-19: An Epidemiological Survey in North-Central Nigeria. J Com Health. 2020. (doi: 10.1007/s10900-020-00881-1).

6. Roy D, Tripathy S, Kar SK, Sharma N, Verma SK, Kaushal V. Study of knowledge, attitude, anxiety and perceived mental healthcare need in Indian population during COVID-19 pandemic. Asian J Psycho. 2020; 51: 102083. (doi: 10.1016/j.ajp.2020.102083).

7. Banik R, Rahman M, Sikder T, Gozal D. COVID-19 in Bangladesh: public awareness and insufficient health facilities remain key challenges. Pub Health. 2020; 183: 50-1. (doi: 10.1016/j.puhe.2020.04.037).

8. Directorate General of Health Service. Corona Info. Ministry of Health and Family Planning, Bangladesh; 2020. Available at: https://corona.gov.bd/ (Accessed: 31 July 2020).

9. Paul TC. Facing Covid-19 challenges with agriculture. Finanl Exp, 2020. Available at: https://thefinancialexpress.com.bd/views/ facing-covid-19-challenges-with-agriculture-1593185280 (Accessed: 31 July 2020).

10. Zafrin A. How Covid-19 has affected agriculture. Dhaka Trib, 2020. Available at: https://www.dhakatribune.com/opinion/op-ed/2020 /05/06/how-covid-19-has-affected-agriculture (Accessed: 31 July 2020).

11. TBS Report. Food sufficiency reels under virus fallout: Brac research. The Business Standard 2020. Available at: https://tbs news.net/economy/agriculture/food-sufficiency-reels-undervirus-fallout-brac-research-88864 (Accessed on 31 July 2020).

12. Rahman A. Save agriculture, save economy! Finan Exp, Dhaka 2020. Available at: https://thefinancialexpress.com.bd/views/saveagriculture-save-economy-1588085510 (Accessed: 31 July 2020). 
13. Afrad MSI, Wadud F, Babu SC. Reforms in agricultural extension service system in Bangladesh. In Babu SC, Joshi, PK, eds. Agricultural Extension Reforms in South Asia: Status, Challenges, and Policy Options. Academic press; 2019: 13-40. https://doi.org/10.1016/B978-0-12-818752-4.00002-3

14. Islam R. Agriculture in the spotlight in Covid-hit Bangladesh. United News Bangladesh, Dhaka 2020. Available at: http://www. unb.com.bd/category/Special/agriculture-in-the-spotlight-incovid-hit-bangladesh/53839 (Accessed: 31 July 2020).

15. Bose R, Hossain MA, Anam MM, Hasnat M, Kabir H. Performance of sub-assistant agricultural officer as a professional leader. Int J Nat Soc Sci. 2014; 1: 41-7. Available at: http://ijnss.org/wpcontent/uploads/2014/10/Article-7-pp-41-47.pdf

16. Person B, Sy F, Holton K, Govert B, Liang A, Sars N. Fear and Stigma: The Epidemic within the SARS Outbreak. Emerg Infect Dis. 2004; 10: 358-63. (doi: 10.3201\%2Feid1002.030750).

17. Saqlain M, Munir MM, Rehman SU, Gulzar A, Naz S, Ahmed Z, Tahir AH, Mashhood M. Knowledge, attitude, practice and perceived barriers among healthcare workers regarding COVID19: a cross sectional survey from Pakistan. J Hos Infect. 2020; 105: 419-23. (doi: 10.1016/j.jhin.2020.05.007).

18. Ajilore K, Atakiti I, Onyenankeya K. College students' knowledge, attitudes and adherence to public service announcements on Ebola in Nigeria: Suggestions for improving future Ebola prevention education programmes. Health Edu J. 2017; 76: 648-60. (doi: 10.1177/0017896917710969).

19. Alahdal H, Basingab F, Alotaibi R. An analytical study on the awareness, attitude and practice during theCOVID-19 pandemic in Riyadh, Saudi Arabia. J Infect Pub Health, 2020; 13(10): 1446-52. (doi: 10.1016/j.jiph.2020.06.015).

20. Banik R, Rahman M, Sikder T, Rahman QM, Pranta MUR. Investigating Knowlede, Attitudes, and Practices related to COVID-19 Outbreak among Bangladesh Young Adults: A webbased cross sectional analysis. [Preprint] 2020. (doi: 10.21203/rs.3.rs-37946/v1).

21. Farhana KM, Mannan KA. Knowledge and Perception towards Novel Coronavirus (COVID-19) in Bangladesh. Int Res J Busi Soc Sci. 2020; 6: 76-9. (doi: 10.2139/ssrn.3578477).

22. Haque T, Hossain KM, Bhuiyan MMR, Ananna SA, Chowdhury $\mathrm{SH}$, Ahmed A, et al. Knowledge, attitude and practices (KAP) towards COVID-19 and assessment of risks of infection by SARSCoV-2 among the Bangladeshi population: An online cross sectional survey. Epidem, [Reprint] 2020. (doi: 10.21203/rs.3.rs24562/v1).
23. Karim A, Akter M, Mazid AHMT, Pulock AH, Aziz TT, Hayee S, et al. Knowledge and Attitudes towards COVID-19 in Bangladesh: Population-level estimation and a comparison of data by phone and online survey methods. [Reprint] 2020. (doi: 10.1101/2020.05.26.20104497).

24. Ferdous MZ, Islam MS, Sikder MT, Mosaddek ASM, ZegarraValdivia JA., Gozal D. Knowledge, attitude, and practice regarding COVID-19 outbreak in Bangladesh: An online-based crosssectional study. Pub Glob Health, [Preprint] 2020; 05: 20105700. (doi: 10.1101/2020.05.26.20105700).

25. Rahman A, Sathi NJ. Knowledge, Attitude, and Preventive Practices toward COVID-19 among Bangladeshi Internet Users. Electron J Gen Med. 2020; 17(5): em245. (doi: 10.29333/ejgm/8223).

26. Umapathi P, Manjunath G, Prasad NC. COVID -19 - An Empirical Study on Knowledge, Awareness, and Practices of Adoni Residents. J Xi'an Uni Arch Tech. 2020; XII(V): 1336-50. (doi: 10.37896/JXAT12.05/1533).

27. Taber KS. The Use of Cronbach's Alpha When Developing and Reporting Research Instruments in Science Education. Res Sci Edu. 2020; 48: 1273-96. (doi: 10.1007/s11165-016-9602-2).

28. Hossain I. Mobile operators struggling to cope with rise in data consumption. Finan Exp, Dhaka 2020. Available at https://www.thefinancialexpress.com.bd/trade/mobile-operatorsstruggling-to-cope-with-rise-in-data-consumption-1587611418 (Accessed: 31 July 2020).

29. Alzoubi H, Alnawaiseh N, Al-Mnayyis A, Abu- Lubad M, Aqel A, Shagahin HA. COVID-19 - Knowledge, Attitude and Practice among Medical and Non-Medical University Students in Jordan. J Pure Appl Microb. 2020; 14: 17-24. (doi: 10.22207/JPAM.14.1.04).

30. Bhagavathula AS, Aldhaleei WA, Rahmani J, Mahabadi MA, Bandari DK. Novel coronavirus (COVID-19) knowledge and perceptions: a survey on healthcare workers. MedRxiv 2020. (doi: 10.1101/2020.03.09.20033381).

31. Giao H, Han NTN, Khanh TV, Ngan VK, Tam VV, An PL. Knowledge and attitude toward COVID-19 among healthcare workers at District 2 Hospital, Ho Chi Minh City. Asian Pac J Trop Med, 2020; 13: 1-6. (doi: 10.4103/1995-7645.280396).

32. Cao J, Hu X, Cheng W, Yu L, Tu WJ, Liu Q. Clinical features and short-term outcomes of 18 patients with corona virus disease 2019 in intensive care unit. Inten Care Med. 2020; 46: 851-3. (doi: 10.1007/s00134-020-05987-7). 
33. Zhang M, Zhou M, Tang F, Wang Y, Nie H, Zhang L, You G.

Knowledge, Attitude, and Practice regarding COVID-19 among

HealthCare Workers in Henan, China. J Hos Infect. 2020;

105(2020): 183-7. (doi: 10.1016/j.jhin.2020.04.012). 